\title{
Anterior cruciate ligament ganglion: case report
}

\author{
Instituto de Ortopedia e Traumatologia, Hospital das Clinicas, Faculdade \\ de Medicina, Universidade de São Paulo, São Paulo, Brazil.
}

- André Pedrinelli

- Fábio Bonini Castellana

- Ricardo Bragança de Vasconcellos Fontes

- Rafael Ferreira Coelho

- Luiz Álvaro de Menezes Fo

\section{....... INTRODUCTION}

A ganglion is defined as a cystic formation, close to joints or tendinous sheaths, frequently found in the wrist, foot or knee. It can be single or multi-lobed, with clear gelatinous, colloid or mucinous content. ${ }^{1}$ Ganglia located at the dorsum of the foot or the wrist, and those close to the interphalangeal articulations are of easy clinical diagnosis, commonly found in clinical practice and usually called 'synovial cysts'. ${ }^{1}$ However, deeper ganglia, such as those found in the forearm, in the periacetabular region or in the suprascapular notch and intra-articular knee ganglia, are difficult to diagnose clinically, especially when not palpable. These are accidentally found when magnetic resonance imaging scans $^{2,3}$ or arthroscopy ${ }^{4-7}$ are performed.

Intra-articular ganglia of the knee are rare and most of them $(62.6 \%)$ are located in the anterior cruciate ligament. ${ }^{1}$ Its etiology remains unknown. The clinical picture of knee ganglia consists of pain and sometimes restriction in the final degrees of extension. ${ }^{4-7}$ These symptoms are especially disturbing to the patient, which makes diagnosis and specific treatment necessary.

We report a case of anterior cruciate ligament ganglion in a 29-year-old patient.

\section{CASE REPORT}

A 29-year-old male patient had been doing competition-level swimming from 1978 to 1998 and he started triathlon training in 1999. In the second half of 2000 , while in a 1000-meter sprint at the end of a mara- thon race, he experienced pain in the posterior aspect of the left knee.

The patient sought medical help in December 2000, and his physical examination revealed pain in the posterior aspect of the left knee and over the popliteal muscle, which worsened when this area was compressed, and a slight increase in volume of this region. He also presented limitation in the range of knee extension. Lachman, jerk, anterior drawer, valgus and varus stress tests were all negative, as were tests for meniscal lesions as well. Radiographs obtained in the anteroposterior and 30degree lateral projections did not reveal any abnormalities. Magnetic resonance imaging revealed a multi-lobed cystic structure adjacent to the anterior cruciate ligament, measuring $3 \times 0.5$ centimeters, which resembled a ganglion cyst (Figures 1 and 2).

The patient underwent knee arthroscopy in November 2000 and had the cystic structure removed (Figure 3). Pathological examination revealed that the mass was a synovial cyst, with a myxoid degeneration focus and light reactive inflammation.

The patient had an excellent recovery, without any pain on the second postoperative day. He also underwent physiotherapy, with emphasis on functional and motor recovery, and in December 2000 received permission to return to light jogging activities. After four months, the patient returned once more to the clinic, having already resumed his usual training routine, including triathlon competitions, without any symptoms.

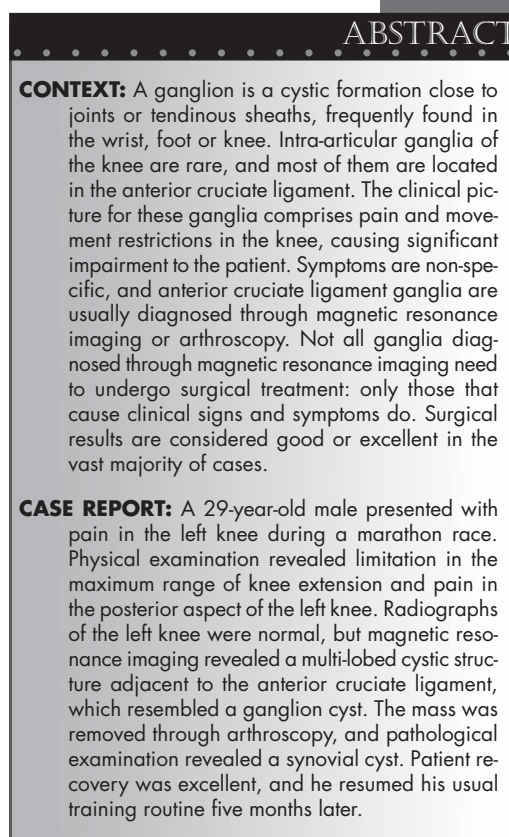

KEY WORDS: Knee. Ganglion. Anterior cruciate ligament. 

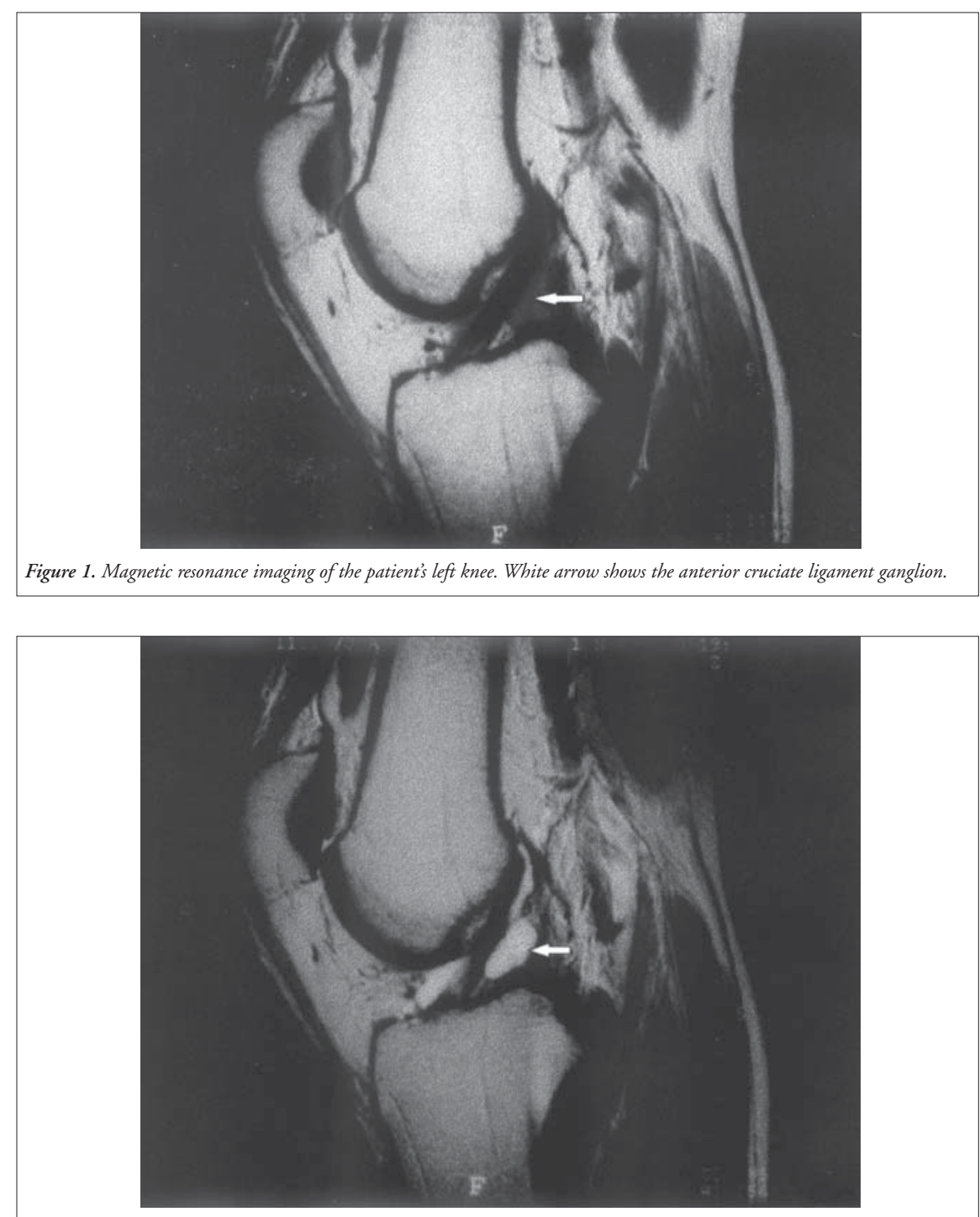

Figure 2. Magnetic resonance imaging of the patient's left knee. White arrow points to the anterior cruciate ligament ganglion.

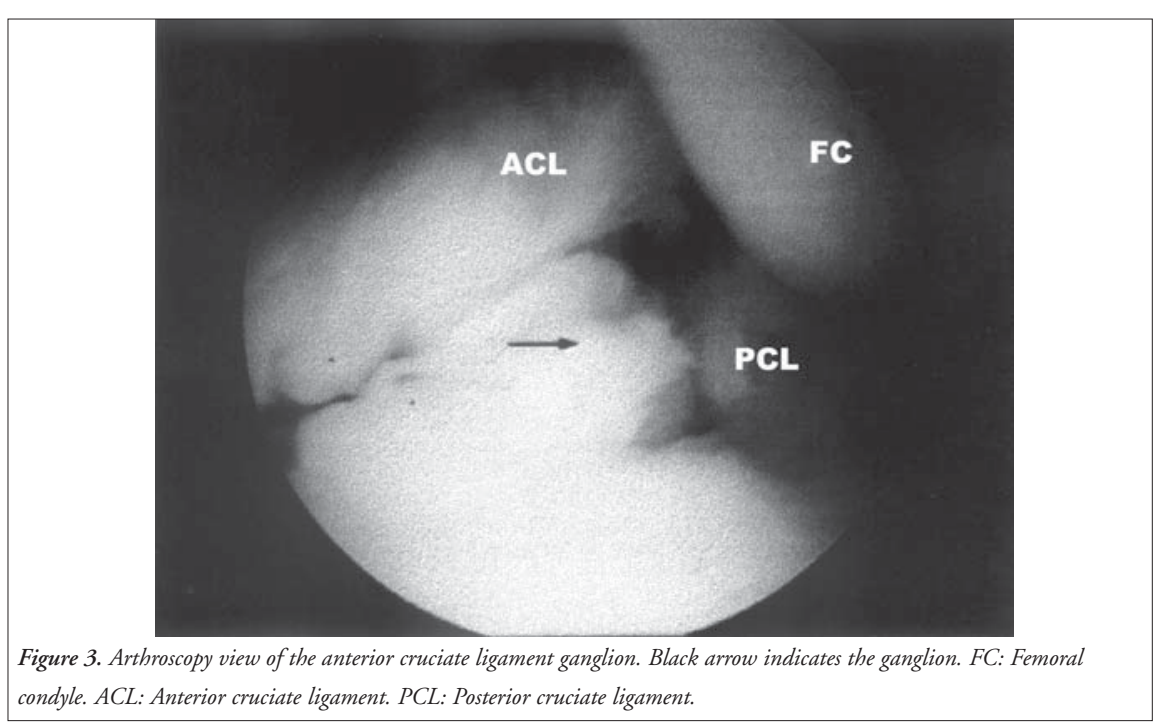

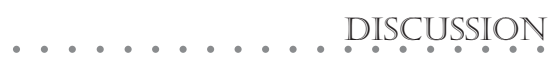

The anterior cruciate ligament ganglion is an uncommon clinical entity. Goldstein and Manacés ${ }^{1}$ reported that $42.1 \%$ of their patients related the beginning of their symptoms to some kind of traumatic event, and that $56.6 \%$ did not possess any trauma history. In the specific case of this patient, the repeated 1,000-meter sprints could be considered traumatic events. Authors who defend the traumatic hypothesis have explained that fusiform dilatation of the ligament fibers occurs secondary to hyaluronic acid infiltration, produced in response to trauma. On the other hand, a congenital anomaly may be the etiology behind ganglia in patients without traumatic history. ${ }^{2,8}$

The most frequently presented symptoms are pain and limitation in the range of knee extension. The data in the work of Goldstein and Manacés ${ }^{1}$ reveal that $79.5 \%$ of their patients with intra-articular knee ganglia complained of pain and $22.9 \%$ of limitation in the range of extension. However, these symptoms are non-specific, and can be present in several other intra-articular diseases, frequently making clinical diagnosis a difficult task. In consequence, the ganglion is usually encountered as a chance finding from magnetic resonance imaging or arthroscopy procedures. The same paper by Goldstein and Manacés states that $91.6 \%$ of the ganglia were chance findings and only $2.4 \%$ were palpable and thus clinically diagnosed. ${ }^{1}$ Magnetic resonance imaging is the safest method for diagnosing the anterior cruciate ligament ganglion, ${ }^{2}$ providing the exact location and dimensions of these ganglia, which vary from 5 to $40 \mathrm{~mm}$, in a non-invasive manner. Furthermore, not all ganglia diagnosed through magnetic resonance imaging need to undergo surgical treatment: only those that cause clinical signs and symptoms do. Bui-Mansfield and Youngberg ${ }^{2}$ reported that $22 \%$ of their patients with intra-articular knee ganglia diagnosed through magnetic resonance imaging underwent arthroscopy later on. On the other hand, a ganglion encountered by chance during arthroscopy can be removed ${ }^{1}$ while carefully avoiding anterior cruciate ligament lesion. There are no reports of recurrence of intraarticular knee ganglia after surgical treatment, and the results are considered "good" or "excellent" in $94.7 \%$ of these cases. ${ }^{1}$ 
1. Goldstein RC, Manacés EL. Ganglion intra-articular do joelho. Comportamento clínico-patológico. Rev Bras Ortop 1999;34:159-64.

2. Bui-Mansfield LT, Youngberg RA. Intra-articular ganglia of the knee: prevalence, presentation, etiology and management. AJR 1997;168:123-7.

3. Burk DL, Dalinka MK, Kanal E, et al. Meniscal and ganglion cysts of the knee: MR evaluation. AJR 1998;150:331-6.

4. Mello, Wilson A Jr., Marchetto Adriano, Amaral Guilherme H. Ganglion de ligamento cruzado anterior simulando lesão de menisco lateral: relato de caso. Rev Bras Ortop 2001;36:47-8.

5. Brown MF, Chir B, Dandy DJ. Intra-articular ganglia of the knee. Arthroscopy 1999;6:322-3.

6. Deutsch A, Veltri DM, Altchek DW, et al. Symptomatic antra- articular ganglia of the cruciate ligaments of the knee. Arthroscopy 1994;10:219-23.

7. Yasuda K, Majima T. Intra-articular ganglion blocking extension of the knee: brief report. J Bone Joint Surg (Br) 1998;70:837.

8. Liu SH, Osti L, Morzayan R. Ganglion cysts of the anterio cruciate ligament: a case report and review of the literature. Arthroscopy 1994;10:110-2.

\section{. PUBLISHING INFORMATION}

André Pedrinelli, MD. Assistant Professor of the Sports Medicine Group and Head Physician of the Prostheses Group, Instituto de Ortopedia e Traumatologia, Hospital das Clínicas, Faculdade de Medicina, Universidade de São Paulo, São Paulo, Brazil.

Fabio Bonini Castellana. Medical Student at the Faculty of Medicine, Universidade de São Paulo, São Paulo, Brazil.

Ricardo Bragança de Vasconcellos Fontes. Medica Student at the Faculdade de Medicina, Universidade de São Paulo, São Paulo, Brazil.

Rafael Ferreira Coelho. Medical Student at the Faculdade de Medicina, Universidade de São Paulo, São Paulo, Brazil.

Luiz Álvaro de Menezes Fº, MD, PhD. Orthopedist, Doctoral degree, Instituto de Ortopedia e Traumatologia, Hospital das Clínicas, Faculdade de Medicina, Universidade de São Paulo, São Paulo, Brazil.

Sources of funding: Not declared

Conflict of interest: Not declared

Date of first submission: March 27, 2002

Last received: March 27, 2002

Accepted: May 7, 2002

\section{Address for correspondence}

André Pedrinelli

Rua General Almério de Moura, 700

São Paulo/SP - Brasil - CEP 05690-080

Tel. (+55 11) 3758-2855

E-mail: pedrinel@uol.com.br

COPYRIGHT@2002, Associação Paulista de Medicina

$\ldots \ldots \ldots \ldots \ldots \ldots$ REMO

CONTEXTO: Um ganglion é uma formação cística próxima a articulações ou bainhas tendinosas, freqüentemente encontrado no punho, pé e joelho. Ganglia intra-articular do joelho são raros, e a maioria destes está localizada no ligamento cruzado anterior. O quadro clínico destes ganglia é composto por dor e limitação de movimento do joelho, causando importante prejuízo ao paciente. Os sintomas são inespecíficos, e ganglia são geralmente diagnosticados por ressonância magnética ou artroscopia. Nem todos os ganglia diagnosticados por ressonância magnética precisam ser submetidos a cirurgia, mas apenas aqueles com sinais e sintomas clínicos. Os resultados cirúrgicos são considerados bons ou excelentes na grande maioria dos casos.
RELATO DE CASO: Um homem de 29 anos apresentou dor no joelho esquerdo durante uma corrida de maratona. O exame físico revelou limitação da extensão máxima do joelho e dor na face posterior do joelho esquerdo. Radiografias do joelho esquerdo foram normais, mas a ressonância magnética revelou uma estrutura cística multilobulada adjacente ao ligamento cruzado anterior, que lembrava um ganglion. A massa foi removida por artroscopia, e o exame patológico revelou um cisto sinovial. A recuperação do paciente foi excelente, e ele retomou sua rotina de treinamento normal cinco meses depois.

PALAVRAS-CHAVE: Joelho. Ganglion. Ligamento cruzado anterior. 